\title{
Pemodelan Debit Sungai Kahayan Menggunakan Jaringan Syaraf Tiruan Berdasarkan Data Hujan dan Evapotranspirasi
}

\author{
Kahayan River Discharge Modeling using Artificial Neural Networks based \\ on Rainfall and Evapotranspiration Data
}

\author{
Very Dermawan $^{1 *}$, Widandi Soetopo ${ }^{1}$, Jano Alpikarigo ${ }^{1}$ \\ ${ }^{1}$ Jurusan Teknik Pengairan, Fakultas Teknik, Universitas Brawijaya, Malang 65145, Indonesia
}

\author{
Article info: \\ Kata kunci: \\ jaringan syaraf tiruan (JST), koefisien \\ korelasi (R), pemodelan debit, nash- \\ sutcliffe efisiensi (NSE).
}

Keywords:

artificial neural network (ANN), correlation coefficient $(\mathrm{R})$, discharge modeling, nash-sutcliffe efisiensi (NSE).

Article history:

Received: 25-11-2019

Accepted: 28-05-2020

*)Koresponden email: peryderma@ub.ac.id

\begin{abstract}
Abstrak
Debit merupakan suatu dasar dalam perencanaan pada sebuah kegiatan pengelolaan sumber daya air. Penentuan nilai debit dapat dilakukan melalui pengukuran secara langsung di lapangan ataupun melalui analisa. Dengan adanya analisa curah hujan terhadap debit sungai dapat menjadi alternatif dalam perencanaan bangunan air, dengan penggunaan metode yang tepat hasil analisa debit akan mendekati nilai hidrologis. Dalam studi ini analisa yang dilakukan menggunakan metode Jaringan Syaraf Tiruan untuk mengetahui hasil pemodelan debit sungai berdasarkan data hujan dan evapotranspirasi dan mengetahui perbandingan debit model dengan debit lapangan. Untuk mengetahui kesesuaian antara debit pemodelan terhadap debit lapangan, maka dilakukan kalibrasi dan pelatihan Jaringan Arsitektur dengan data latih 6 sampai 9 tahun serta verifikasi debit model dengan pembagian data 4 sampai 1 tahun dari data sisa kalibrasi. Pelatihan jaringan arsitektur digunakan epoch 500 sampai 2000. Uji yang digunakan yaitu Mean Square Error (MSE), Mean Absolute Error (MAE), Kesalahan Relatif (Kr), Koefisien Korelasi (R), Nash-Sutcliffe Efisiensi (NSE). Hasil pengujian debit model menggunakan Jaringan Syaraf Tiruan terhadap debit lapangan berdasarkan hasil pengujian didapatkan bahwa di pembagian data latih 7 tahun dan data uji 3 tahun dengan epoch 1000 yang memenuhi kriteria dan memiliki nilai paling baik, berdasarkan nilai Nash-Sutcliffe Efisiensi (NSE), dan Koefisien Korelasi $(R)$.
\end{abstract}

\begin{abstract}
Discharge is one of the bases in a plan for a water resource management activity. Determination of the discharge value can be done through measurements directly in the field or through analysis. With the analysis of rainfall on river discharge can be an alternative in water structure planning, with the right methods the results of the discharge analysis will approach with real hydrological condition. In this study, the analysis was carried out using the Artificial Neural Network method to find out the results of the modelling of river discharge based on rainfall and evapotranspiration data and to know the comparison between model discharge and real discharge. To discover the compatible between modelling discharge with real discharge, calibration and learning of Networks has been done with 6 until 9 years learning data, and verification of the model discharge by 4 until 1 year from the rest of the calibration data. In network learning, epoch 500 until 2000 are used. The error tests are Mean Square Error (MSE), Mean Absolute Error (MAE), Relative Error (Kr), Correlation Coefficient (R), Nash-Sutcliffe Efficiency (NSE). The results of comparison
\end{abstract}


between model discharge using the Artificial Neural Network with real discharge, based on the test results discover that in the distribution of 7 year learning data and 3 year test data with epoch 1000 that compatible with criteria and had the best value, based on result of Nash-Sutcliffe Efficiency (NSE) value, and the Correlation Coefficient (R)

Kutipan: Dermawan, V., Soetopo, W., \& Alpikarigo, J. (2020). Pemodelan Debit Sungai Kahayan Menggunakan Jaringan Syaraf Tiruan Berdasarkan Data Hujan Dan Evapotranspirasi. Jurnal Teknik Pengairan. https://doi.org/10.21776/ub.pengairan.2020.011.01.05

\section{Pendahuluan}

Sungai Kahayan dengan panjang kurang lebih $600 \mathrm{~km}$ dan lebar $500 \mathrm{~m}$ melewati beberapa wilayah kabupaten seperti Kabupaten Gunung Mas, Kabupaten Kapuas, Kabupaten Katingan, Kabupaten Murung Raya, Kabupaten Pulang Pisau, Kota Palangka Raya, dan bermuara di Laut Jawa. DAS Kahayan merupakan daerah yang memiliki iklim tropis, dengan sejumlah besar curah hujan sepanjang tahun, hal ini berlaku bahkan untuk bulan terkering. Pada setiap musim penghujan terjadi banjir pada daerah sekitar bantaran Sungai Kahayan

Dengan banjir yang terjadi di sekitar bantaran sungai maka diperlukan adanya analisis data hidrologi sehingga menunjang perencanaan bangunan pengendali banjir yang akan menjadi solusi dari permasalahan banjir tersebut. Namun, banyaknya pos hidrologi yang bermasalah, baik permasalahan teknis, kesalahan pembacaan, dan data yang hilang atau tidak tercatat, serta ketidakakuratan data menyebabkan terhambatnya analisa hidrologi sehingga permasalahan banjir masih terjadi. Penguapan dan evapotranspirasi berdampak pada masyarakat di tingkat ekonomi dan ekologi. Mengenai pertimbangan ekonomi, dengan pemantauan dan pengawasan terhadap fenomena ini, rekomendasi untuk praktek irigasi dapat dirumuskan seperti peningkatan perencanaan program irigasi dan memungkinkan estimasi yang lebih akurat dari produksi pertanian. Secara ekologis, evaporasi dan evapotranspirasi mengatur iklim lokal dengan meningkatkan fenomena kabut (Lary et al. 2016). Peningkatan representasi pola spasial proses hidrologi harus menjadi pertimbangan utama dalam pemodelan dengan model yang didistribusikan secara spasial, yang akan memungkinkan prakiraan banjir dan kekeringan yang lebih baik. Selain itu, hasilnya memberikan wawasan kepada para pengembang set data evaporasi dan dapat menjadi panduan untuk pengembangan di masa mendatang. Namun, replikasi dari metodologi yang diusulkan untuk mengevaluasi dataset evaporasi harus diterapkan di wilayah lain dengan kondisi hidroklimat yang berbeda, dan dengan model hidrologi dan permukaan tanah yang berbeda (Dembélé et al. 2020).

Pembelajaran menggabungkan berbagai prosedur kompleks. Pembelajaran mesin (ML) adalah subdivisi dari kecerdasan buatan berdasarkan proses pembelajaran biologis. Pendekatan ML berkaitan dengan desain algoritma untuk belajar dari data yang dapat dibaca mesin. ML mencakup domain utama seperti data mining, sulit untuk-aplikasi program, dan aplikasi perangkat lunak. Ini adalah kumpulan dari berbagai algoritme (misalnya jaringan syaraf, mesin vektor pendukung, peta pengorganisasian sendiri, pohon keputusan, hutan acak, berbasis kasus penalaran, pemrograman genetik, dll.) yang dapat memberikan regresi multivariate, nonlinear, nonparametric atau klasifikasi. Kemampuan pemodelan metode berbasis ML telah menghasilkan ekstensif aplikasi dalam sains dan teknik (Lary et al. 2016).

Melalui perkembangan zaman teknologi, ditemukannya teknologi yang bernama Jaringan Syaraf Tiruan (Artificial Neural Network) yang mampu memodelkan data statistik non-linier (Kusumadewi 2003). Dengan kemampuan dari teknologi Jaringan Syaraf Tiruan dapat dijadikan inovasi dalam memodelkan data hidrologi sehingga permasalahan teknis yang dapat menghambat pembangunan dapat teratasi. Dalam studi ini penulis memodelkan debit sungai berdasarkan data curah hujan dan evapotranspirasi melalui uji model berbasis teknologi jaringan saraf tiruan dengan metode Backpropagation dan menggunakan Program Matlab R2015A (Haribowo, Dermawan, and Yudha 2018). Inti dari pemodelan / pemetaan numerik adalah prediksi, yang diperoleh dengan menghubungkan satu set variabel dalam ruang input ke satu set variabel respon dalam ruang keluaran melalui model (Zhang and Goh 2016). 
Jaringan Syaraf Tiruan dapat menjadi salah satu pilihan metode dalam menganalisa hubungan curah hujan terhadap debit. Berikut merupakan beberapa keunggulan jaringan syaraf tiruan, yaitu:

1. dapat mewakili setiap fungsi nonliniear pada data yang memberikan kompleksitas yang cukup pada suatu jaringan terlatih

2. mampu menemukan hubungan antara data masukan/input sample yang berbeda

3. mampu menetralisasikan hubungan dari himpunan kecil data walau terdapat data yang tersisa, namun tetap relatif kuat meskipun terdapat masukan data yang rusak atau hilang.

Dalam penelitian ini tujuan yang ingin dicapai adalah:

1. Mengetahui hasil Kalibrasi debit model Sungai Kahayan menggunakan Jaringan Syaraf Tiruan

2. Mengetahui hasil hasil Verifikasi debit model dengan menggunakan Jaringan Syaraf Tiruan terhadap data debit di Sungai Kahayan

3. Mengetahui hasil Validasi debit model terhadap debit di Sungai Kahayan.

\section{Material dan Metode}

\subsection{Lokasi Studi}

Provinsi Kalimantan Tengah, dengan ibu kota Palangka Raya terletak antara $0^{\circ} 45^{\prime}$ Lintang Utara, $3^{\circ} 30^{\prime}$ Lintang Selatan dan $111^{\circ}-116^{\circ}$ Bujur Timur. Provinsi Kalimantan Tengah memiliki luas wilayah mencapai $153,564 \mathrm{~km}^{2}$. Provinsi Kalimantan Tengah memiliki 11 (sebelas) sungai besar dan tidak kurang dari 33 (tiga puluh tiga) sungai kecil/anak sungai, keberadaannya menjadi salah satu ciri khas Provinsi Kalimantan Tengah.

Pada studi ini lokasi yang digunakan adalah DAS Kahayan, yang berarada pada Provinsi Kalimantan Tengah. Sungai Kahayan bermuara pada 3 kabupaten/kota antara Kota Palangkaraya, Kabupaten Gunung Mas, dan Kabupaten Pulang Pisau dan juga berakhir bermuara di Laut Jawa. Sungai Kahayan memiliki luas mencapai $81,648 \mathrm{~km}^{2}$, panjang $600 \mathrm{~km}$, lebar $500 \mathrm{~m}$, kedalamannya mencapai $7 \mathrm{~m}$ (Gambar 1).

Memahami fisika penguapan dimulai sejak awal abad terakhir ketika Bowen menunjukkan bagaimana energi tersedia partisi antara fluks panas laten dan fluks panas sensibel dapat ditentukan dengan menggunakan gradien suhu dan kelembaban. Penman memadukan konsep keseimbangan energi dengan aerodinamis aspek penguapan untuk mengembangkan persamaan memperkirakan penguapan pada tahun 1948 yang diadopsi secara luas oleh air ahli. Dalam dekade berikutnya, beberapa teori dan model eksperimental untuk mengevaluasi teknik penguapan telah banyak digunakan (Hassan 2013).

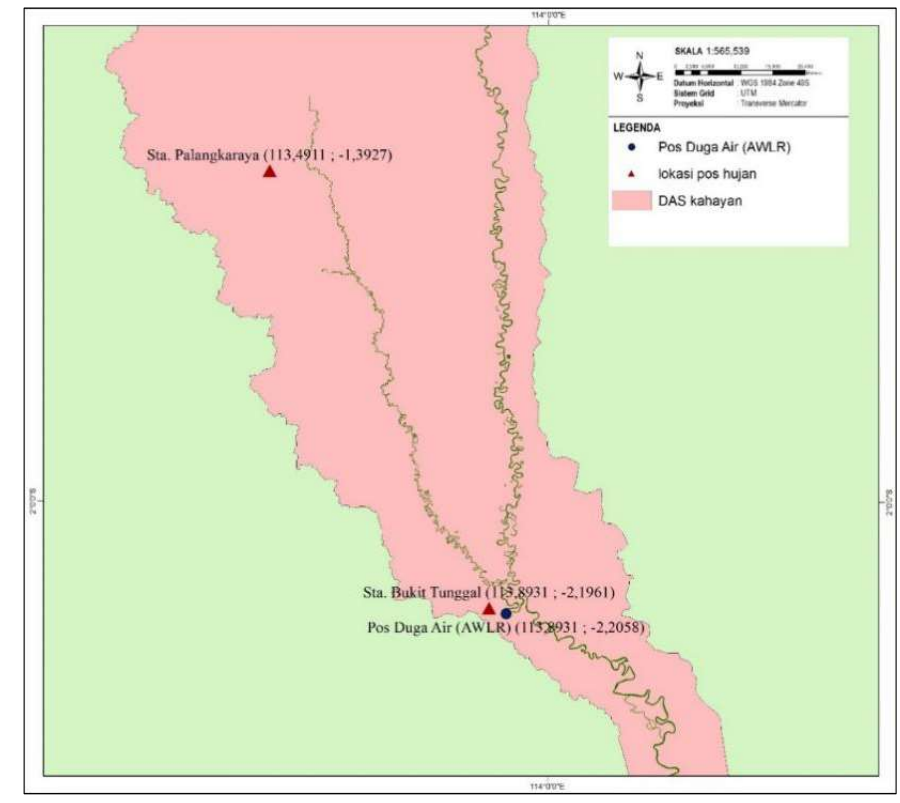

Gambar 1. Lokasi Daerah Studi 


\subsection{Data}

Data yang diperlukan yaitu:

1. Peta lokasi studi

2. Data curah hujan harian tahun $2008-2017$

3. Data klimatologi harian tahun 2008-2017

\subsection{Pengolahan Data Input}

Studi pemodelan debit Sungai Kahayan, diawali dengan melakukan pengolahan data Evapotranspirasi dari data klimatologi stasiun BMKG Tjilik Riwut, curah hujan rerata daerah berasal dari Stasiun Hujan Bukit Tunggal, dan Stasiun Hujan Palangkaraya, kemudian pemodelan debit jaringan syaraf tiruan menggunakan program Matlab 2015A.

\subsection{Evapotranspirasi}

Dalam perhitungan nilai evapotranspirasi digunakan metode Penman. Dimana metode ini "menggabungkan metode transfer massa dan metode neraca energi untuk metode neraca energi untuk menghitung evaporasi. Selanjutnya evapotranspirasi dihitung dengan mengalikan nilai evaporasi dengan suato konstan empiris." Hasil penggabungan kedua metode tersebut menghasilkan persamaan berikut (Triatmodjo 2008):

$$
E_{t}=\frac{\beta E_{n}+E}{\beta+1}
$$

Dengan:

$\mathrm{E}_{\mathrm{t}}=$ evapotranspirasi potensial $(\mathrm{mm} / \mathrm{hari})$

$\mathrm{E}=$ evaporasi (mm/hari)

$\mathrm{E}_{\mathrm{n}}=$ kedalanan penguapan dalam $\mathrm{mm} / \mathrm{hari}$

$\mathrm{B}=$ fungsi temperature

\subsection{Hujan Rerata Daerah}

Curah hujan yang diperlukan untuk penyusunan suatu rancangan pemanfaatan air adalah curah hujan rerata daerah. Salah satu metode perhitungan curah hujan rerata daerah menggunakan metode Aljabar sebagai berikut (Takeda and Sosrodarsono 2003):

$$
\bar{R}=\frac{1}{n}\left(R_{1}+R_{2}+\cdots+R_{n}\right)
$$

Dengan:

$$
\begin{array}{ll}
\bar{R} & =\text { curah hujan daerah }(\mathrm{mm}) \\
\mathrm{N} & =\text { jumlah pos pengamatan } \\
R_{1}, R_{2}, R_{n} & =\text { curah hujan di tiap titik } \\
& \text { pengamatan (mm) }
\end{array}
$$

\subsection{Uji Ketiadaan Trend}

Data berkala yang nilainya menunjukan suatu gerakan yang berjangka panjang dan mempunyai kecenderungan mengarah menuju ke satu arah menaik atau menurun disebut dengan pola atau trend (Soewarno 2015). Apabila suatu data menunjukan suatu trend maka dapat diuji dengan analisa lanjutan yaitu analisa regresi.

Uji ketiadaan trend mempunyai beberapa metode yaitu:

a. Uji Peringkat Metode Sperman

b. Uji Mann Whitney

c. Uji Cox Stuart

\subsection{Uji Stasioner}

Apabila deret berkala tersebut tidak menunjukkan adanya trend sebelum data deret berkala digunakan untuk analisis lanjutan harus dilakukan uji stasioner, namun apabila menunjukkan adanya trend maka deret berkala tersebut dapat dilakukan analisis rnenurut garis trend yang dihasilkan (Soewarno 2015). Dalam uji stasioner terdapat dua jenis pengujian: 
a. Uji Kestabilan Nilai Varian (Uji F)

b. Uji Kestabilan Nilai Rata-rata (Uji T)

\subsection{Pemodelan Debit Menggunakan Jaringan Syaraf Tiruan}

Banyak algoritma pelatihan yang tersedia pada aplikasi Matlab R2015A, pada studi ini metode pelatihan yang digunakan adalah metode Backpropagation yang merupakan algoritma pembelajaran yang terawasi dan digunakan oleh preceptron dengan banyak lapisan untuk mengubah bobot yang terhubung dengan neuron (Kusumadewi 2003).

Dalam pemodelan menggunakan Jaringan Syaraf Tiruan terdapat beberapa kriteria sebagai berikut:

\subsection{Perhitungan Error}

Perhitungan error bertujuan untuk mengukur keakurasian jaringan dalam mengenali pola yang diberikan. Ada dua macam perhitungan error yang digunakan, yaitu (Makridakis 1999):

a. Mean Square Error (MSE)

$$
M S E=\frac{1}{N} \sum_{i=1}^{N}\left(Q_{o}-Q_{m}\right)^{2}
$$

b. Mean Absolute Error (MAE)

$$
M A E=\frac{1}{N} \sum_{i=1}^{N}\left|Q_{o}-Q_{m}\right|
$$

\subsection{Kesalahan Relatif $(K R)$}

Perhitungan nilai kesalahan relatif adalah perhitungan absolute dari output jaringan dan output target dibagi output target yang telah dirata-ratakan. Untuk membuktikan bahwa hasil output jaringan dan output target mempunyai nilai yang tidak jauh berbeda rumus perhitungan kesalahan relatif adalah sebagai berikut:

$$
K R=\frac{Q_{o}-Q_{m}}{Q_{o}} \cdot 100 \%
$$

\subsection{Koeffisien Korelasi $(R)$}

Analisis korelasi merupakan metode statistik yang digunakan untuk mengetahui hubungan antara dua variabel. Tujuan analisis ini ialah untuk mendapatkan pola dan hubungan antara dua variabel atau lebih. Berikut rumus persamaan koeffisien korelasi:

$$
R=\frac{N \sum_{i=1}^{N} Q_{o} Q_{m}-\sum_{i=1}^{N} Q_{o} \cdot \sum_{i=1}^{N} Q_{m}}{\sqrt{N \sum_{i=1}^{N} Q_{o}^{2}-\left(\sum_{i=1}^{N} Q_{o}\right)^{2}} \sqrt{N \sum_{i=1}^{N} Q_{m}{ }^{2}-\left(\sum_{i=1}^{N} Q_{m}\right)^{2}}}
$$

Tabel 1. Kriteria Nilai Koefisien Korelasi

\begin{tabular}{cc}
\hline Nilai R & Interpretasi \\
\hline $0-0,19$ & Sangat Rendah \\
$0,20-0,39$ & Rendah \\
$0,40-0,59$ & Sedang \\
$0,60-0,79$ & Kuat \\
$0,8-1$ & Sangat Kuat \\
\hline \multicolumn{2}{l}{ Sumber: (Sugiyono 2009) }
\end{tabular}

\subsection{Efisiensi Nash-Sutchliffe (NSE)}

Dalam jaringan syaraf tiruan, salah satu indikator yang menentuan keandalan hasil model yaitu $\mathrm{R}^{2}$. Karena indikator tersebut digunakan untuk mengevaluasi kinerja model dalam hal membandingkan antara debit model dengan data target. Berikut persamaan $\mathrm{R}^{2}$ (Suprayogi et al. 2013): 
Dengan:

$$
N S E=1-\frac{\sum\left(Q_{0}-Q_{m}\right)^{2}}{\sum\left(Q_{0}-\bar{Q}_{0}\right)^{2}}
$$

$$
\begin{array}{ll}
\mathrm{Q}_{0} & =\text { Debit target }\left(\mathrm{m}^{3} / \text { det }\right) \\
\mathrm{Q}_{\mathrm{m}} & =\text { Debit pemodelan }\left(\mathrm{m}^{3} / \text { det }\right)
\end{array}
$$

Tabel 2. Kriteria Nilai NSE

\begin{tabular}{cc}
\hline Nilai NSE & Interpretasi \\
\hline NSE $>0,75$ & baik \\
$0,36<$ NSE $<0,75$ & Memenuhi \\
NSE $<0,36$ & Tidak Memenuhi \\
\hline Sumber: (Suprayogi et al. 2013)
\end{tabular}

Sumber: (Suprayogi et al. 2013)

\section{Hasil dan Pembahasan}

Data input selama 10 tahun sebelum dimasukan dalam aplikasi pemodelan akan diuji melalui uji kualitas data. Data yang didapatkan tidak langsung digunakan dalam pemodelan, dikarenakan untuk menghindarai kesalahan teknis dan human error. Maka perlu adanya pengujian data.

Dalam studi ini data input menggunakan periode bulanan dari tahun. Berikut hasil pengujian yang diperoleh yaitu :

1. Uji Ketiadaan Trend

Dari hasil uji Ketiadaan Trend didapat bahwa data curah hujan rerata daerah lulus uji terkecuali uji Spearman dengan derajat kepercayaan 5\%.

2. Uji Stasioner

Dari hasil uji Stasioner didapat bahwa data curah hujan rerata daerah lulus uji. Data uji diterima karena data bersifat homogen.

Pengolahan Data Menggunakan Matlab R2015A

Dari hasil kalibrasi awal pada aplikasi Matlab R2015A didapat komposisi jaringan arsitektur sebagai berikut:

\begin{tabular}{ll}
\multicolumn{1}{c}{ Tabel 3. Hasil kalibrasi jaringan arsitektur } \\
$\begin{array}{c}\text { Spesifikasi } \\
\text { Arsingan }\end{array}$ & \multicolumn{1}{c}{$\begin{array}{c}\text { Hasil Pengaturan } \\
\text { Kalibrasi }\end{array}$} \\
\hline Network type & $\begin{array}{l}\text { feed-forward } \\
\text { backprop }\end{array}$ \\
\hline Input data & $\begin{array}{l}\text { Hujan rerata daerah, } \\
\text { dan Evapotranspirasi }\end{array}$ \\
\hline Target data & Debit sungai \\
\hline Training function & TRAINLM \\
\hline $\begin{array}{l}\text { Adaptation } \\
\text { learning function }\end{array}$ & LEARNGDM \\
\hline $\begin{array}{l}\text { Performance } \\
\text { function }\end{array}$ & MSE \\
\hline Number of layer & dicoba 2 dan 3 layer \\
\hline $\begin{array}{l}\text { Number of } \\
\text { neurons }\end{array}$ & 2 neurons \\
\hline & $\begin{array}{l}\text { LOGSIG untuk } \\
\text { hidden layer }\end{array}$ \\
\cline { 2 - 2 } Transfer function & $\begin{array}{l}\text { PURELIN untuk } \\
\text { output layer }\end{array}$ \\
\hline
\end{tabular}


Dalam pelatihan jaringan terdapat Grafik Performance, Grafik Training State, dan Grafik Regresion yang diperoleh dari hasil pelatihan jaringan (training). Berikut merupakan tampilkan Grafik hasil pelatihan pada jaringan:

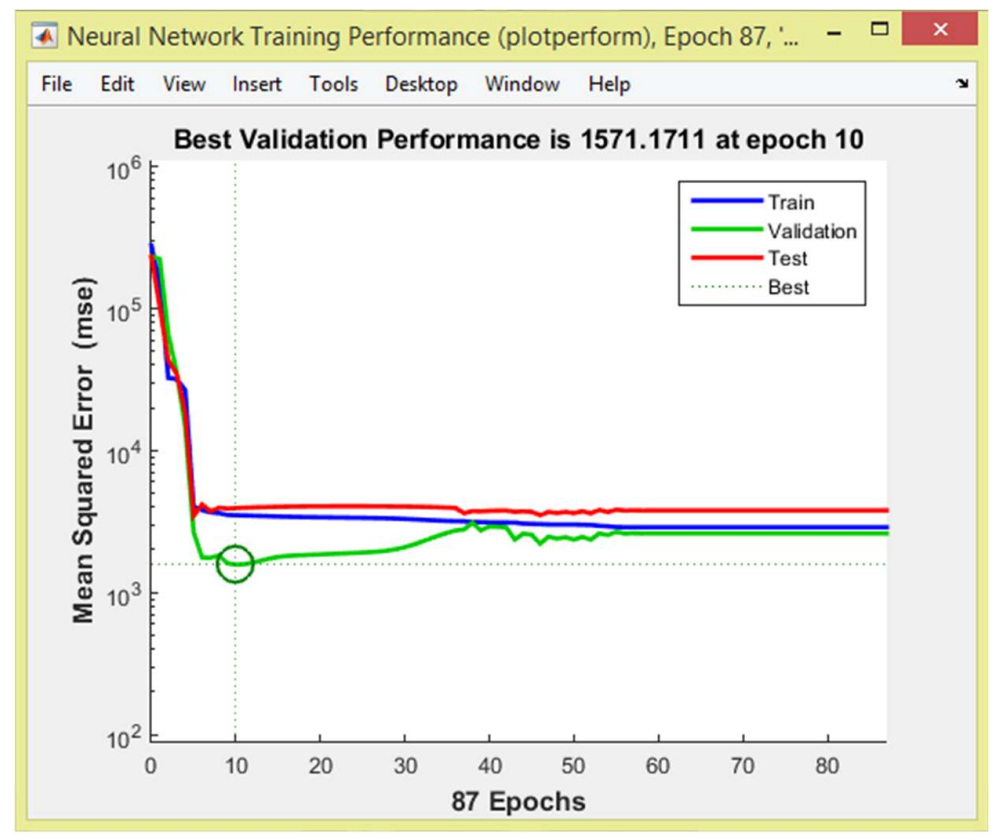

Gambar 2. Grafik Performance Training

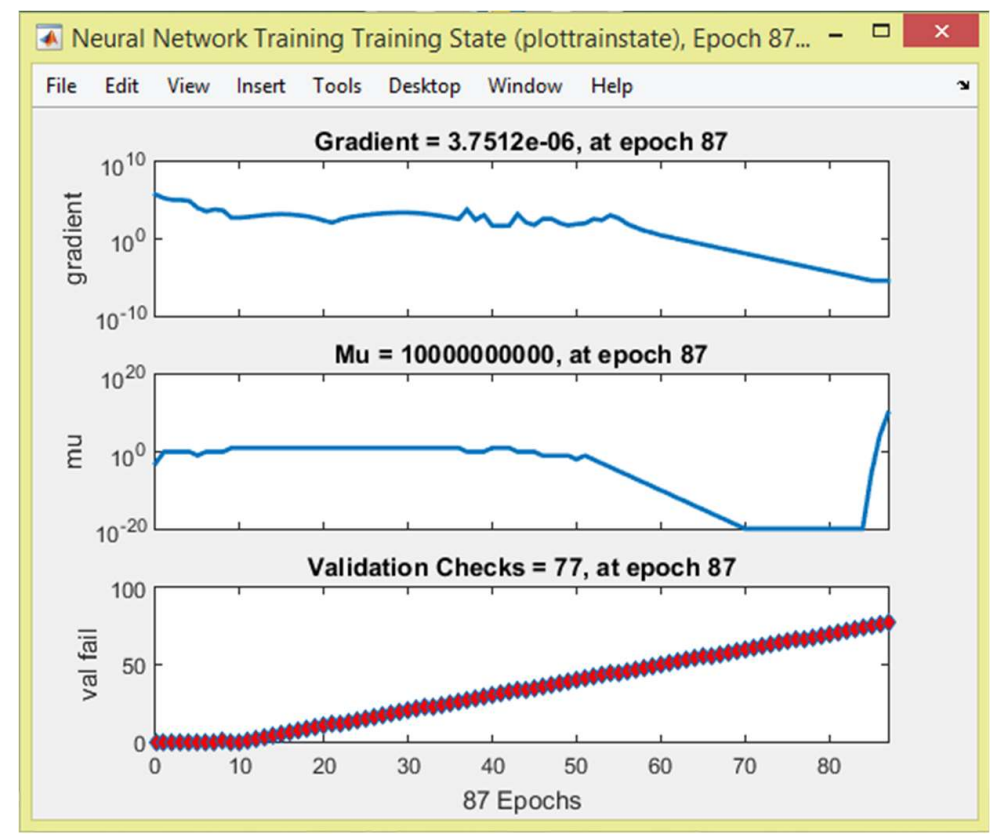

Gambar 3. Grafik Training State Training 


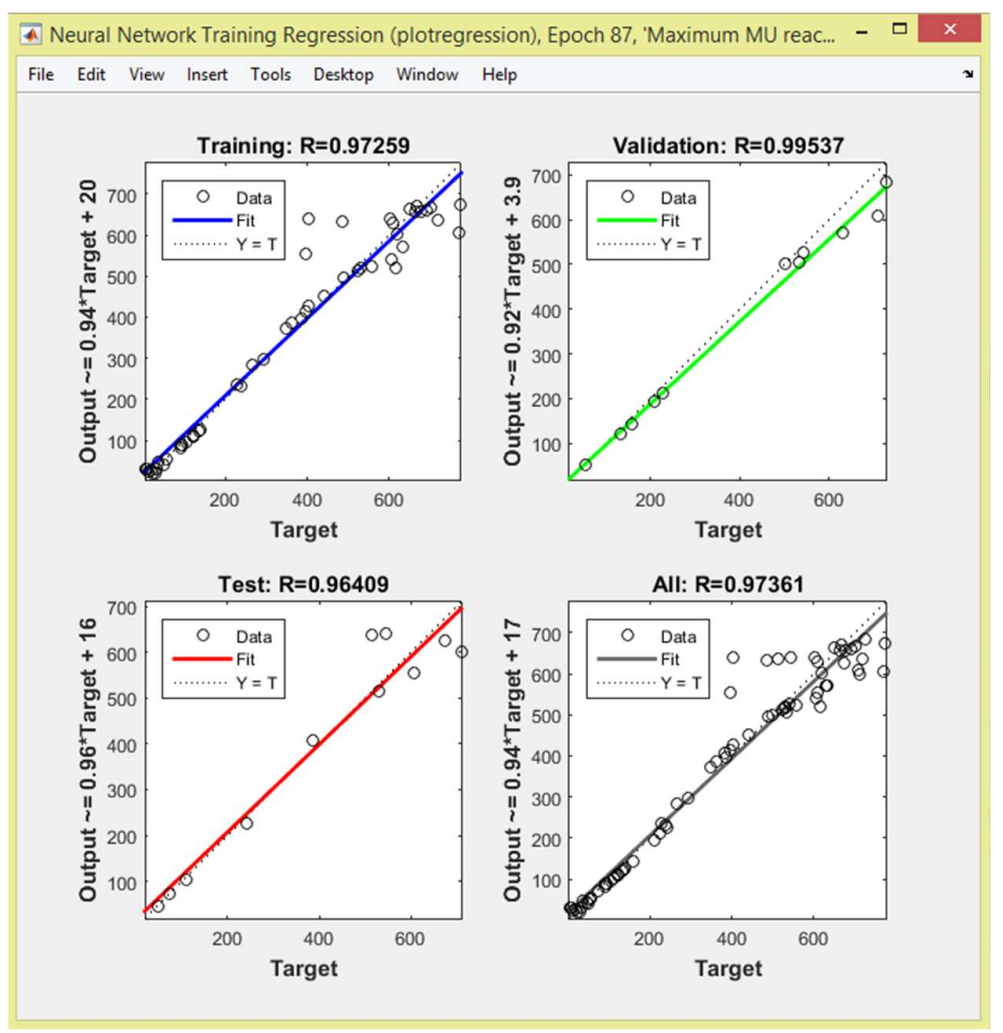

Gambar 4. Grafik Regresion Training

Setelah dilakukan kalibrasi pembuatan jaringan arsitektur dan dilakukan kombinasi pembagian data latih dan data uji, layer dan epochs, didapat 32 kombinasi jaringan arsitektur, Tabel 4 merupakan rekapitulasi validasi dan verifikasi jaringan.

Dari hasil kalibrasi pembuatan arsitektur jaringan dan dilakukan pelatihan jaringan serta pengujian kesalahan dan keandalan debit model didapat persamaan jaringan dengan hasil keandalan terbaik, yaitu pola persamaan jaringan (2-2-1) dengan jumlah input pada input layer sebanyak $2\left(\mathrm{x}_{1}\right.$ dan $\left.\mathrm{x}_{2}\right)$ yaitu hujan rerata daerah, dan evapotranspirasi, dengan 2 hidden layer $\left(\mathrm{z}_{1}\right.$ dan $\mathrm{z}_{2}$ ) dengan 2 neuron, dan 1 output layer $\left(\mathrm{y}_{\mathrm{i}}\right)$, Serta dengan data latih sebanyak 7 tahun dan data uji sebanyak 3 tahun, pada jumlah epochs 1000 didapat hasil keandalan berdasarkan nilai NSE sebesar 0.901 dan nilai koefisien korelasi sebesar 0.95.

Tabel 4. Hasil Validasi dan Verifikasi data latih 6 tahun dan data uji 4 tahun

\begin{tabular}{|c|c|c|c|c|c|}
\hline Layer & EPOCH & MSE & MAE & $\mathrm{R}$ & NSE \\
\hline \multirow{4}{*}{2} & 500 & $5,139.36$ & 48.86 & 0.94 & 0.886 \\
\hline & 1000 & $5,667.52$ & 49.59 & 0.94 & 0.874 \\
\hline & 1500 & $6,350.39$ & 52.60 & 0.93 & 0.859 \\
\hline & 2000 & $5,566.15$ & 48.94 & 0.94 & 0.877 \\
\hline \multicolumn{6}{|c|}{ data latih 6 tahun dan data uji 4 tahun } \\
\hline Layer & EPOCH & MSE & MAE & $\mathrm{R}$ & NSE \\
\hline \multirow{4}{*}{3} & 500 & $6,012.89$ & 54.32 & 0.93 & 0.867 \\
\hline & 1000 & $5,614.99$ & 46.95 & 0.94 & 0.876 \\
\hline & 1500 & $7,032.35$ & 47.98 & 0.93 & 0.844 \\
\hline & 2000 & $5,063.48$ & 44.45 & 0.94 & 0.888 \\
\hline
\end{tabular}




\begin{tabular}{|c|c|c|c|c|c|}
\hline Layer & EPOCH & MSE & MAE & $\mathrm{R}$ & NSE \\
\hline \multirow{4}{*}{2} & 500 & $6,923.75$ & 57.83 & 0.93 & 0.844 \\
\hline & 1000 & $5,492.79$ & 50.03 & 0.94 & 0.876 \\
\hline & 1500 & $5,579.78$ & 49.99 & 0.94 & 0.874 \\
\hline & 2000 & $5,112.74$ & 45.14 & 0.94 & 0.885 \\
\hline \multirow{4}{*}{3} & 500 & $5,812.13$ & 54.63 & 0.93 & 0.869 \\
\hline & 1000 & $4,390.98$ & 37.48 & 0.95 & 0.901 \\
\hline & 1500 & $5,214.35$ & 44.80 & 0.94 & 0.882 \\
\hline & 2000 & $4,621.24$ & 41.79 & 0.95 & 0.896 \\
\hline \multicolumn{6}{|c|}{ data latih 8 tahun dan data uji 2 tahun } \\
\hline Layer & EPOCH & MSE & MAE & $\mathrm{R}$ & NSE \\
\hline \multirow{4}{*}{2} & 500 & $6,933.23$ & 56.79 & 0.84 & 0.703 \\
\hline & 1000 & $7,610.55$ & 61.68 & 0.83 & 0.674 \\
\hline & 1500 & $8,060.65$ & 63.44 & 0.81 & 0.655 \\
\hline & 2000 & $6,933.23$ & 56.79 & 0.84 & 0.703 \\
\hline \multirow{4}{*}{3} & 500 & $7,236.13$ & 58.93 & 0.83 & 0.690 \\
\hline & 1000 & $8,015.20$ & 57.80 & 0.81 & 0.657 \\
\hline & 1500 & $7,836.61$ & 62.43 & 0.83 & 0.664 \\
\hline & 2000 & $7,603.57$ & 55.89 & 0.83 & 0.674 \\
\hline \multicolumn{6}{|c|}{ data latih 9 tahun dan data uji 1 tahun } \\
\hline Layer & EPOCH & MSE & MAE & $\mathrm{R}$ & NSE \\
\hline \multirow{4}{*}{2} & 500 & $4,149.72$ & 30.33 & 0.87 & 0.751 \\
\hline & 1000 & $3,991.25$ & 27.24 & 0.88 & 0.760 \\
\hline & 1500 & $3,114.75$ & 24.06 & 0.93 & 0.813 \\
\hline & 2000 & $4,143.37$ & 31.19 & 0.87 & 0.751 \\
\hline \multirow{4}{*}{3} & 500 & $3,860.36$ & 28.40 & 0.88 & 0.768 \\
\hline & 1000 & $4,266.93$ & 27.05 & 0.88 & 0.744 \\
\hline & 1500 & $4,077.85$ & 28.01 & 0.88 & 0.755 \\
\hline & 2000 & $4,144.23$ & 28.13 & 0.88 & 0.751 \\
\hline
\end{tabular}

\section{Kesimpulan}

Berdasarkan hasil Kalibrasi pemodelan debit menggunakan Jaringan Syaraf Tiruan dilakukan pembuatan jaringan arsitektur sebanyak 32 jaringan, dengan mencoba berbagai kombinasi pembagian data pelatihan dan data uji dengan perbandingan perbandingan 6 tahun/4 tahun, 7 tahun 13 tahun, 8 tahun/2 tahun, 9 tahun/1 tahun, dengan mencoba kombinasi jumlah layer sebanyak 2 dan 3 layer, serta dengan mencoba jumlah Epoch sebesar 500, 1000, 1500, 2000 Epoch. Didapat persamaan pola jaringan arsitektur 2 input data, 2 hidden layer, 1 output layer (2-2-1) dengan epochs sebesar 1000.

Berdasarkan hasil Verifikasi jaringan arsitektur dengan pola jaringan 2 input data, 2 hidden later, 1 output layer (2-2-1) dengan komposisi jumlah pembagian data latih dan data uji dengan perbandingan 7 tahun/3 tahun, serta jumlah Epoch sebesar 1000 Epoch memiliki hasil terbaik dimana debit model dan debit lapangan memiliki hubungan korelasi yang sangat kuat dengan nilai koefisien korelasi pada jaringan ini memiliki nilai sebesar 0.95.

Berdasarkan hasil Validasi jaringan arsitektur dengan pola jaringan 2 input data, 2 hidden later, 1 output layer (2-2-1) dengan komposisi jumlah pembagian data latih dan data uji dengan perbandingan 7 tahun/3 tahun, serta jumlah Epoch sebesar 1000 Epoch menghasilkan nilai terbaik dimana debit model termasuk dalam kategori keandalan baik dengan nilai NSE sebesar 0.901. 


\section{Saran}

Berdasarkan pemodelan debit pada Sungai Kahayan menggunakan Jaringan Syaraf Tiruan, maka disarankan beberapa hal berikut:

1. Dari hasil pemodelan debit pada Sungai Kahayan menggunakan jaringan syaraf tiruan dapat dijadikan masukan untuk perencanaan bangunan pengendali banjir di daerah sekitar Sungai Kahayan.

2. Analisa yang digunakan pada saat training pemodelan jaringan arsitektur dapat divariasikan menggunakan metode-metode yang lainnya sehingga keandalan dan keakuratan hasil debit pemodelan dapat lebih ditingkatkan.

3. Selain menggunakan data curah hujan dan data klimatologi data-data pendukung lain yang berhubungan juga dapat digunakan untuk meningkatkan keandalan hasil pemodelan debit.

\section{Daftar Pustaka}

Dembélé, Moctar et al. 2020. "Potential of Satellite and Reanalysis Evaporation Datasets for Hydrological Modelling under Various Model Calibration Strategies." Advances in Water Resources.

Haribowo, Riyanto, Very Dermawan, and Nevandria Yudha. 2018. "Application of Artificial Neural Network For Defining The Water Quality in The River." Civil and Environmental Science.

Hassan, Mohamed. 2013. "Evaporation Estimation for Lake Nasser Based on Remote Sensing Technology." Ain Shams Engineering Journal.

Kusumadewi, Sri. 2003. Artificial Intelligence (Teknik Dan Aplikasinya). Yogyakarta: Graha Ilmu.

Lary, David J., Amir H. Alavi, Amir H. Gandomi, and Annette L. Walker. 2016. "Machine Learning in Geosciences and Remote Sensing." Geoscience Frontiers.

Makridakis. 1999. Metode Dan Aplikasi Peramalan. 2nd ed. Jakarta: Binarupa Aksara.

Soewarno. 2015. Analisis Data Hidrologi : Menggunakan Metode Statistika Dan Stokastik: Seri Hidrologi. Yogyakarta: Graha Ilmu.

Sugiyono. 2009. Metode Penelitian Kuantitatif Kualitatif Dan R\&D. Bandung: Penerbit Alfabeta.

Suprayogi, Imam, Yohana Lilis Handayani, Lita Darmayanti, and Trimaijon. 2013. "Analisis Hujan Debit Pada DAS Indragiri Menggunakan Pendekatan Model IHACRES.” Konferensi Nasional Teknik Sipil 7 (KONTEKS).

Takeda, Kensaku, and Suyono Sosrodarsono. 2003. "Hidrologi Untuk Pengairan." Editor Sosrodarsono, S. PT Pradnya Paramita: Jakarta.

Triatmodjo, B. 2008. "Hidrologi Terapan." Beta Offset.

Zhang, Wengang, and Anthony T.C. Goh. 2016. "Multivariate Adaptive Regression Splines and Neural Network Models for Prediction of Pile Drivability." Geoscience Frontiers. 